\title{
編地のかさ高さ測定 法*
}

一厚さの測定法を中心として—

岡 野 志 郎**

\section{1. かさ高さの概念と定義}

“加さ高さ”という言葉から連想するむのは，毛布， ふとん綿など容積のあるものであって, 直接, 編地を連 想することは少ない. 編地の場合は，一般に“厚さ”で表 わされるほうが多い. しかし, 編物であってむバルキー セーターなどでば厚さ”よりも, “かさ高さ”のほうを問 題にされることが多い. との場合でも“かさ高さ”と“厚 さ”とはそれぞれ独立に使われるのではなく，「厚さの 割りにかさがない」というような表現のしかたがされて いる. この場合 “厚さ”は製品の両面にある圧力の加え られた状態で測られており，“かさ高さ”はただ目で見 た感じ，または両面にほとんど圧力の加わらない状態で 測られたあのである.すなわち，“厚さ”は長さの因子 だけで表わされているのに対し, “かさ高さ”は, 体積 または比容積で表わされていると考えられる・

編地の“かさ高さ”を,「単位重量あたりの編地の容 積」と定義する. との考えは JIS でも採用されてお り, “かさ高さ”測定法をつぎのように決めている.

かさ高度：重さおよび厚さからつぎの式で算出する.

(小数点以下ふたけたまで)

加さ高度 $\left(\mathrm{cm}^{3} / \mathrm{g}\right)=\mathrm{t} / \mathrm{w} \times 10^{3}$

ここに w: 重さ $\left(\mathrm{g} / \mathrm{m}^{2}\right)$

$\mathrm{t}$ : 厚さ $(\mathrm{mm})$

\section{2. かさ高さ測定法}

かさ高さをうえのように定義すると，かさ高さを求め るためには，編地の重さと厚さを正しく求めるととが必 要になる.との 2 種の因子を比べると, 重さの測定より あ厚さの測定のほうがよりむずかしい.

\section{1 重さの測定法}

重さの測定は, J I S, B S, A S TMなど, いずれ
あ同じ方法で, 一定面積の試料を正確に切り取り, その 重量を測るものである.

一例として J I S 法をあげる

(i) 正量

試料から試験片を 3 枚以上採取し, それぞれの絶乾重、 量をはかり,つぎの式で正量を算出し, その平均値を単 位面積当たりで表わし, 試験片の大きさを付記する.

(小数点以下ひとけたまで)

正量 $\left(\mathrm{g} / \mathrm{m}^{2}\right)=w^{\prime} \times(1+r / 100) \times 1 / a$

ここに, $w^{\prime}$ : 絶乾重量 $(\mathrm{g})$

$r$ : 公定水分率 $(\%)$

$a:$ 試験片の面積 $\left(\mathrm{m}^{2}\right)$

（2）標準状態の重さ

試料から試験片を 3 枚以上採取し，それぞれ水分平衡 に至らせた状態の重さ（g）をはかり，その平均値を単 位面積当たり $\left(\mathrm{g} / \mathrm{m}^{2}\right)$ で表わし, 試験片の大きさを付 記する・(小数点以下ひとけたまで）

この試験法では試料を一定面積の大きさに正しく切り 取るととが必要で，実際には $10 \mathrm{~cm} \times 10 \mathrm{~cm}$ ，または 30 $\mathrm{cm} \times 30 \mathrm{~cm}$ 程度の大きさに切られているが，できるだけ 大きい面積のほうが結果のばらつきはすくない.

\section{2 厚さの測定法}

厚さを測定する際に, 試料面に圧力を加えずに測るこ とは非常にむずかしい．面圧を加えないために光学的な 測定法などあ考えられているが，てれにあ欠点があって 実用されていない.したがって，厚さの測定には一定圧 力のもとで測るよりほかに方法がない.

A S TMでは厚さを一定の圧力が加えられたときの厚 さと定義している・またB Sでも同じように厚さを定義 している.

問題はこの一定圧力をいくらにするかにある・厚さは 荷重によって大きく変化し, 編地, ブランケットなどで は荷重の小さい範囲での変化が大きい. 
現在，広く行なお机ているJ I S，B S，ASTMの 試験法について簡単に述べる。

a. J I S 法

(1) 厚さ

試料加ら5 か所以上について厚さ測定器により一定侍 間，初荷重の香以とで厚さ $(\mathrm{mm})$ をは汃りその平均值 で表わす（小数点以下ふたけたまで)。

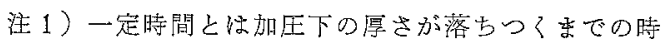
間をいう。普通は $10 \mathrm{sec}$ 間がの艺焉しい。

注: 2) 初㑞需普通の編地 $7 \mathrm{~g} / \mathrm{cm}^{2}$ ペイル編地 $3 \mathrm{~g} / \mathrm{cm}^{2}$

(2) 備溇

厭さ測定器のプレッサーフートは $5 \mathrm{~cm}^{2}$ を用いるの を原則とするが，とれによらないときは条件を付記する。

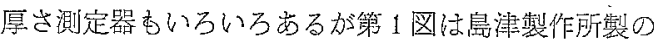

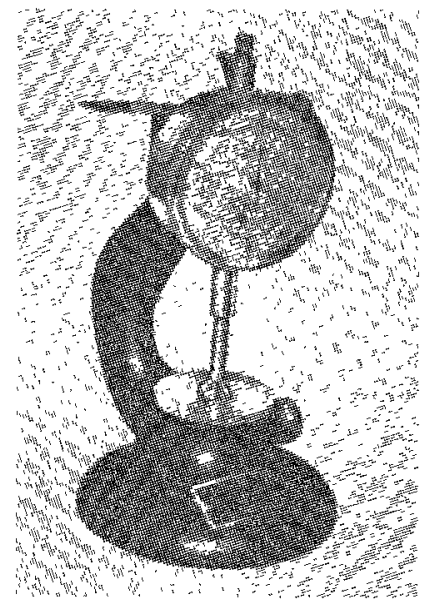

（筷 1 図）愿さ测定器 (島膤製作所)

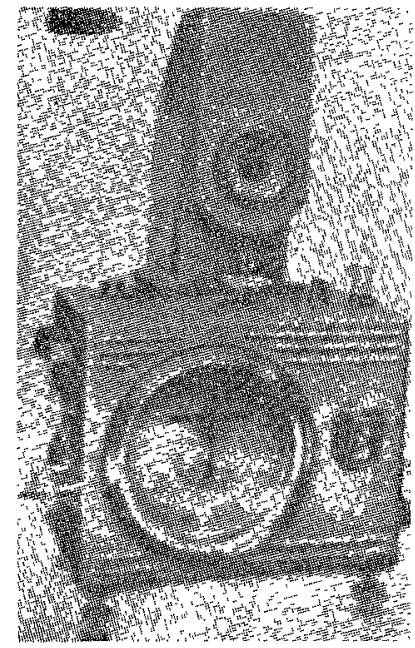

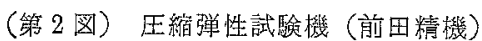

厚さ測定器である。第 2 図住压縮弾性試験機（前田精

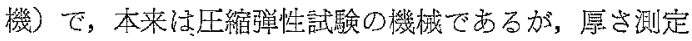
加容易に行なえる.乙扎估荷重とプレッサーフートの 面積が容易に变えられる。

b. B S 法

(1) 箟囲

ての方法は，素材によって定められた一定王力のもと で生地の是さを正礁に测定するのに利用される。

(2) 原珼

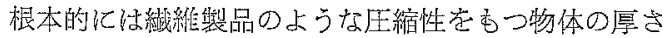
を，一定の环力を加え，それを保持したときに生地に上 ってへだてられた 2 枚の平面の間の距離を正確に測定す ることである(この 1 枚の平面はプレッサーフートで他 の1放往合でる).

(3) 洁置

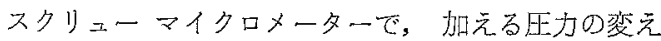
られるすの.

(4) 試料 調整

生地它標準状態で $24 \mathrm{hr}$ ，放置して調整し，同じ標準 状態の屯とで試駼定行なう。

(5) 試験試料

しわのない部分から採取し，伸ばさないとと。

(6) 試料数

生地の翼なる部分からすくなくこも 10 枚は採取する。

(7) 㩭作

プレッサーフートと台の表西克きれいにし，0調整 を行なう・プレッサーフートを上げて，しわのない試 料を㖘力を扣えずに台にの甘、プレッサーフートをさげ る・プレッサーフートの隆下速度は約 2/1000in/sec, 程度にする。加压時間は生地によって指定せられた時間 または経験的に決かられた時間で，指針が止まるまで 要する洔間の約 $20 \%$ の時間保持する.

（8）結果の表示

つざの項目を明示する。

唇さの平均值

プレッサーフートの大きd

於元た圧力

加圧時間

注 1）加える王力としては，つ窟に㳻められたどれか を用いること加推桨されている。
$0.1 \mathrm{lb} / \mathrm{in}^{2}$ または $10 \mathrm{~g} / \mathrm{cm}^{2}$
$1 \mathrm{lb} / \mathrm{in}^{2}$ または $100 \mathrm{~g} / \mathrm{cm}^{2}$
$10 \mathrm{lb} / \mathrm{in}^{2} ま t / 1000 \mathrm{~g} / \mathrm{cm}^{2}$

使朋するプレッサーフートの面積 


$\begin{array}{rc}\left(\mathrm{in}^{2}\right) & \left(\mathrm{cm}^{2}\right) \\ 1 & 0.25 \\ 5 & 1 \\ 10 & 2 \\ 50 & 8 \\ 100 & 16\end{array}$

な拉，イキリスて使用されている厚さ则定器の例を示 すと第 3 恳は, ヒールの唇さ棓 (Heal's Th1ckness Gauge). 第 4 図柱,レイノルズ ブレンソンの織物厚さ 則定器 (Reynolds \& Branson Cloth Thickness

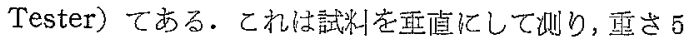

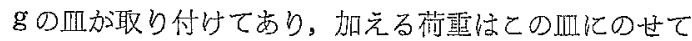
調整する・技もりをのせない崵合は且の自重の $5 \mathrm{~g}$ 方試 粗に加わる。

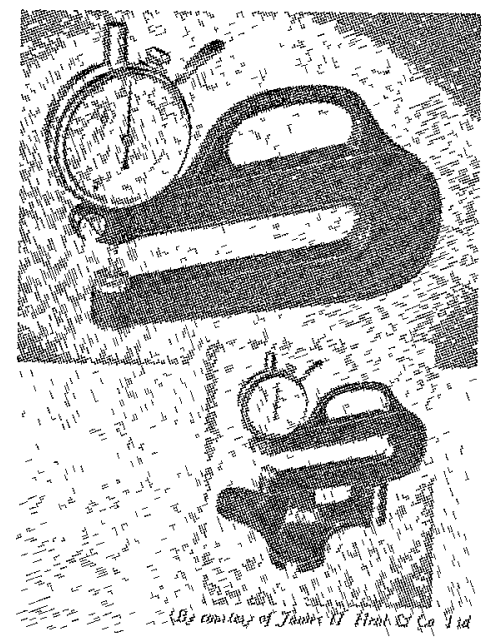

(第 3 困) ヒ一ル厚さ訓

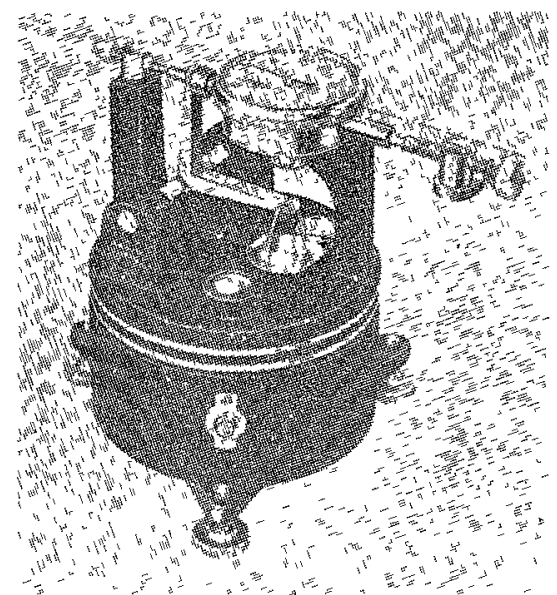

(第 4四) レイノルズブレンンン織物愿さ测定器

c. ASTM法

(1) 適用範囲

螎地，織物，不織布なよ゙のすべての縺維品に適用され
Ђ.

(2) 䇥放

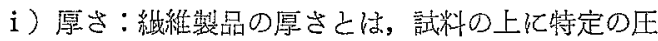
力を加壳たときの平行な 2 平面の間の距離をい j.

11) 压力：プレンサーフートによって試料沉方る れた平方インチ当たりのポント数定いう。

（第 1 表）加える荷重の䉇囲

\begin{tabular}{|c|c|c|}
\hline 素材の種類 & 例 & 荷重の你国（psi） \\
\hline 柔 (Soft) & $\begin{array}{l}\text { ブランケット } \\
\text { フリース } \\
\text { 綽 物 } \\
\text { 不織布 } \\
\text { 紡毛裴品 }\end{array}$ & $0 \quad 005 \sim 050$ \\
\hline $\begin{array}{l}\text { 中 䦎 } \\
\text { (Moderate) }\end{array}$ & $\begin{array}{l}\text { 梳毛裂品 } \\
\text { シーツ類 } \\
\text { カーペット }\end{array}$ & $0.02 \sim 20$ \\
\hline $\begin{array}{l}\text { 堅 } \\
\text { (Firm) }\end{array}$ & 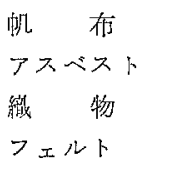 & $01 \sim 10$ \\
\hline
\end{tabular}

鞄 1 流に試料に加える圧力の範四を示す。この表は種 々の素忉について荷重の選択を行なうための一般们な指 釗を示したものて岕る。一般的にはての表の筷四の最も

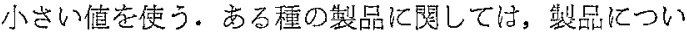
てのASTM試跧法によって荷重定めているものがあ b.

\section{(3) 装置}

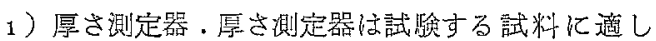
た大きさ它すち，定められた生力の土5％以内の誤差 てあるとと. 台とプレッサーフートはとすに平らて平 行て，その差は 0.0005 in 以内て，0.001 n の差を示す ケージをむち，スケールの精宸は０0005 in 以内である とと. 台㤝，市くなくとあプレッサーフートと同じ大

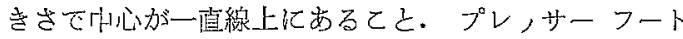
あるい《試颜試料よりあ大きい台学使用するのは，試験

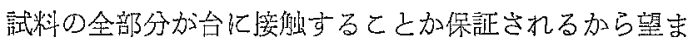
しいことてある.プレッサーフートは普通円形のもの 加使用される.しかし，細いテープのようなるのには長 方形のフート加適当である.

第 2 表比現在市販 (アメリカ内て) されている厚さ測 定器の例走示寸.

第5，6図杜フラシールのコンプレッソメーター 
（第 2 丧） 厚さ測定器の例

\begin{tabular}{|c|c|c|c|c|}
\hline 称 & 型 & 発 売 元 & $\begin{array}{l}\text { プレッ } \\
\text { サー } \\
\text { フート } \\
\text { 径 } \\
\text { (in) }\end{array}$ & $\begin{array}{l}\text { 荷 重 } \\
\text { (psi) }\end{array}$ \\
\hline Ames & & $\begin{array}{l}\text { The Ames } \\
\text { Co, }\end{array}$ & 0.375 & 3.4 \\
\hline Armstrong & $\mathrm{CS}-47$ & $\begin{array}{l}\text { Custom } \\
\text { Scientific } \\
\text { Instruments }\end{array}$ & $\begin{array}{l}0.375 \\
0.500 \\
0.750\end{array}$ & $\begin{array}{l}2.2,4.5 \\
\text { または } 6.8 \\
1.3,2.5 \\
\text { または } 3.8 \\
0.6,1.1 \\
\text { また } 1.7\end{array}$ \\
\hline $\begin{array}{l}\text { Armstrong } \\
\text { Indention } \\
\text { Machine }\end{array}$ & $\mathrm{CS}-71$ & \begin{tabular}{l|} 
Custom \\
Scientific \\
Instruments
\end{tabular} & $\begin{array}{l}0.125 \\
0.375 \\
1.125\end{array}$ & $\begin{array}{r}82 \sim 3300 \\
11 \sim 3300 \\
1 \sim 300\end{array}$ \\
\hline$C \& R$ & CS-55 & $\mid \begin{array}{l}\text { Custom } \\
\text { Sc1entific } \\
\text { Instruments }\end{array}$ & $\begin{array}{l}0.125 \\
0.375 \\
1.125 \\
3\end{array}$ & $\begin{array}{l}25 \sim 120 \\
0.3 \sim 110 \\
0.03 \sim 10 \\
0.004 \sim 1.4\end{array}$ \\
\hline $\begin{array}{l}\text { Carpet } \\
\text { Thickness } \\
\text { Gauge }\end{array}$ & CS-108 & $\begin{array}{l}\text { Custon } \\
\text { Scientific } \\
\text { Instruments }\end{array}$ & $\begin{array}{l}1 \\
3\end{array}$ & $\begin{array}{l}0.02 \sim 10 \\
0.03 \sim 1.0\end{array}$ \\
\hline $\begin{array}{l}\text { Compresso- } \\
\text { meter }\end{array}$ & & Frazier & \begin{tabular}{l|l}
1 & \\
3 & \\
5 & 0
\end{tabular} & $\begin{array}{c}0.1 \sim 30 \\
0.01 \sim 0.3 \\
0.005 \sim 0.1\end{array}$ \\
\hline Federal & $\mathrm{Y}-4046$ & $\begin{array}{l}\text { Federal } \\
\text { Products } \\
\text { Corp }\end{array}$ & $\begin{array}{lll}0 & 375\end{array}$ & $3.4 \sim 90$ \\
\hline $\begin{array}{l}\text { Low } \\
\text { Pressure } \\
\text { Gauge }\end{array}$ & $\mathrm{CS}-49$ & $\left|\begin{array}{l}\text { Custom } \\
\text { Scientific } \\
\text { Instruments }\end{array}\right|$ & $1\left(\mathrm{~cm}^{2}\right)$ & $0.01 \sim 1.5$ \\
\hline $\begin{array}{l}\text { Randall- } \\
\text { Stickney }\end{array}$ & & $\begin{array}{l}\text { F. E. } \\
\text { Randall Co, }\end{array}$ & $\begin{array}{l}0.125 \\
0.250 \\
0.375 \\
1.25\end{array}$ & $\begin{array}{l}1.1 \\
0.6 \\
1.2 \\
0.1\end{array}$ \\
\hline T. M. I & 551 & $\begin{array}{l}\text { Testing } \\
\text { Machine } \\
\text { Inc. }\end{array}$ & 0.60 & 8 \\
\hline T. M I & $551 \mathrm{M}$ & $\begin{array}{l}\text { Testing } \\
\text { Machine } \\
\text { Inc. }\end{array}$ & 0.60 & 8 \\
\hline
\end{tabular}

(Frazier, Compressometer) てプレッサーフート は直径 $1 \mathrm{~m}$ が普通て，他の大きさのむのと取り換える ととがてさる，厚さは下のダイヤルて測り，上のダイヤ ル隹重が指示されるようになっている。

\section{(4) 武験試州}

i）しわや変形のないるのて素材学代表すると考えら れるもの.

ii）編地のはしから幅の約 $10 \%$ より内側からランダ ムに採取する・プレ,サーフートの面樻よりも 約 $10 \%$ 程度大きい円形何り取る。

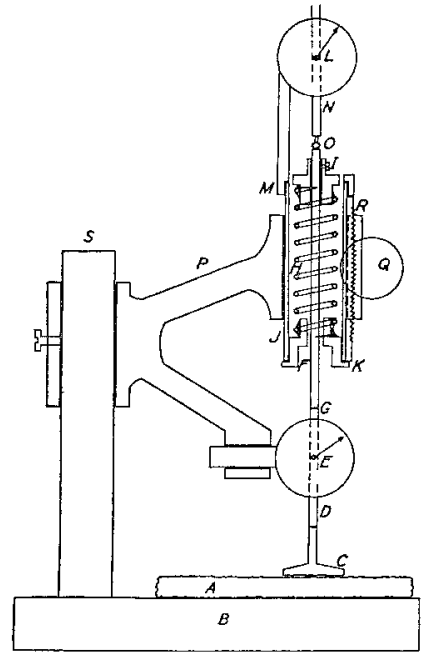

(第5図) フラジール マンプレッソ メーター略図

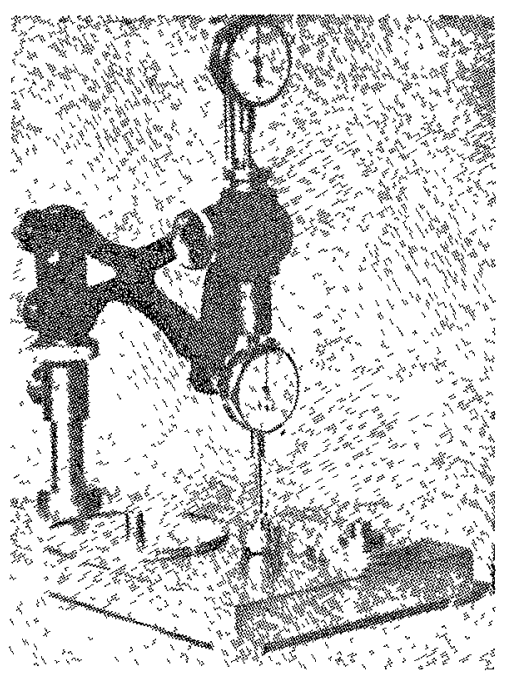

(第 6园) フラシール゙ュンプレッン ムータ一斥筧

\section{（5）試料の調整}

標隼状態に放置して，水分平衡させたのちに試験 する。

(6) 試料数

i） $95 \%$ の確率水隼で, $\pm 5 \%$ 平均精度の試験結果 が得られるように試料数をつぎの式からきめる。 $n=0.154 v^{2}$

ととに, $n$ : 試料数

v：同じ菜材ての過去の試験データから得ら れた試検結果の変動率

ii） vが不明のときは10回側定する。10 回測定はv が $8 \%$ ときに等しい。 
（第 3 表）厚さ 測 定 の 例

\begin{tabular}{|c|c|c|c|c|c|c|c|c|c|c|c|c|c|c|c|c|}
\hline No. & $w$ & $c$ & $w \times c$ & $c / w$ & $d$ & $l$ & $l / d$ & $t_{1}$ & $t_{2}$ & $t_{3}$ & $t_{4}$ & $t_{5} t_{1} / d\left|t_{2} / d\right|$ & $\mid t_{3} / d t_{4} / d$ & $\left|t_{5} / d\right|$ & $t_{0}$ & $\mathrm{t}_{0} / d$ \\
\hline & $|35.0|$ & 44.6 & 1561.0 & 1.274 & 125 & 3040 & 4. 32 & 817 & 716 & 602 & 556 & 5106.545 & 5 & 4.08 & 399 & 3.19 \\
\hline-2 & 26.2 & 29.2 & 765.0 & 1.115 & 149 & 3350 & 22.48 & 603 & 542 & 464 & 406 & 3604.053 & 3.112 .72 & 2.41 & 448 & 3.01 \\
\hline-3 & $\left.27.4\right|^{3}$ & 31.6 & 865.8 & 1.153 & 139 & 3180 & 22.88 & 590 & 538 & 453 & 410 & $367 \mid 4.243 .87$ & $|3.26| 2.95 \mid$ & 2.64 & 432 & 3.11 \\
\hline 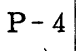 & 28.43 & 38.2 & 1084.9 & 1.345 & 145 & 3000 & 20.69 & 568 & 534 & 460 & 418 & \begin{tabular}{l|l|l|}
378.92 & 3.68 \\
\end{tabular} & .88 & 2.61 & 416 & 2.87 \\
\hline-5 & $28.4 \mid$ & 42.8 & 1215.5 & 1.507 & 150 & 3010 & 20.07 & 589 & 524 & 446 & 410 & \begin{tabular}{l|l|l|l|}
361 & 3.93 & 3.49 & 2
\end{tabular} & $2.97 \mid 2.73$ & 2.41 & 417 & 2.78 \\
\hline I - 1 & 37.03 & 35.6 & 1317.2 & 0.962 & 134 & 3490 & 25.04 & 1258 & 1200 & 1094 & 1028 & \begin{tabular}{l|l|l|}
925 & 9.39 & 8.96 \\
\end{tabular} & 8.167 .67 & 6.90 & & \\
\hline-2 & 34.83 & 36.4 & 12 & 1.046 & 128 & 2890 & $22 . \dot{5} 8$ & 1025 & 962 & 868 & 811 & $730|8.017 .52| 6$ & 6.786 .34 & 5.70 & & \\
\hline-3 & 35.43 & 39.2 & 13 & 1.107 & 112 & 2860 & 25.54 & 1013 & 948 & 855 & 805 & $735|9.04| 8.467$ & 7.637 .19 & 6.56 & & \\
\hline$I-4$ & $34.4 \mid 4$ & 41.2 & 1417.3 & 1.198 & 128 & 2840 & 22.19 & 990 & 915 & 830 & 780 & 7167.7 & 6.486 .09 & 5.59 & & \\
\hline 2 & 21.63 & 30.4 & 656.6 & 1.407 & 164 & 3740 & 22.80 & 1279 & 1212 & 1104 & 1046 & 9707.807 .396 & 6.736 .38 & 5.91 & 111 & 6. 79 \\
\hline-2 & 32.4 & 42.2 & 1367.3 & 1.302 & 106 & 2550 & 24.06 & 779 & 720 & 657 & 622 & $584|7.35| 6.79 \mid 6$ & 6.205 .87 & 5.51 & & 7.11 \\
\hline$F-3$ & $|32.6|$ & 44.0 & 1434.4 & 1.350 & 109 & 2400 & 22.02 & 750 & 689 & 630 & 599 & $567|6.88| 6.32 \mid 5$ & 5.785 .50 & 5.20 & 719 & 6.60 \\
\hline F- 4 & $|32.6| 4$ & 45.6 & 1486.6 & 1.399 & 109 & 2200 & 20.18 & 729 & 683 & 626 & 595 & $\left.564|6.69| 6.27\right|^{5}$ & 5.745 .46 & 5.17 & 668 & 6.13 \\
\hline
\end{tabular}

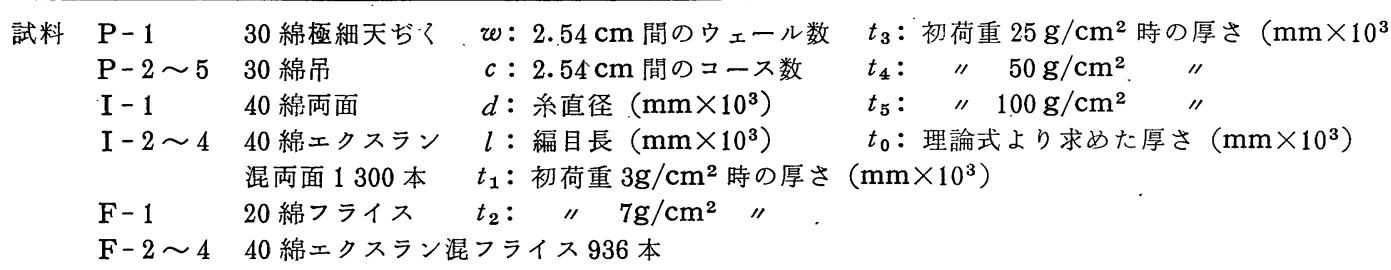

(7) 操作

i ）素材の自然な状態をそこなわないように注意して 試料を取り扱わねばならない. 試験試料を台の上 にのせ,プレッサーフートを試料に接触させる. この場合, プレッサーフートに接触するのは生 地の表側にする. 徐々に圧力を加える. その速度 は $5 \mathrm{sec}$ 間で全圧力がかかるような速度にする. 全圧力を加えて $5 \mathrm{sec}$ 間放置してゲージの值を読 む.

ii）他の試料についても同じ操作を行なう。

iii）厚さの平均值を計算する.

(8) 報告

つぎの事項を報告する.

i) 試料の明細

ii ) 厚さ測定器の形

iii）プレッサーフートと試料の大きさ

iv) 圧力

V) 加圧時間

vi) 試料数

vii）厚さの平均値

\section{3. 編地の厚さ測定の実測例}

紡績系を使って編んだ, 平編地, ゴム編地, 両面編地 について厚さ測定を行なった実測例をつぎに示す. 測定
条件はつぎのとおりである.

\section{1 測 定 条 件}

（1）測定機：圧縮弾性試験機（前田精機）

（2）試料の重敉枚数：3枚（交互にウエールが直角 に交わるように重ねた）

（3）プレッサーフートの面積： $5 \mathrm{~cm}^{2}$

(4) 圧力: $3 \mathrm{~g} / \mathrm{cm}^{2}, 7 \mathrm{~g} / \mathrm{cm}^{2}, 25 \mathrm{~g} / \mathrm{cm}^{2}, 50 \mathrm{~g} /$ $\mathrm{cm}^{2}$, および $100 \mathrm{~g} / \mathrm{cm}^{2}$

（5）圧力放置時間：10 sec

(6) 測定回数：5回

第 3 表にその結果を示す.

\section{4. 編地の厚さ測定試験についての考察}

\section{1 編地の重ね枚数}

厚さ測定時の試料の重ね枚数についてはどの試験法で あはっきり定められていない。なにも定められていない のは 1 枚で測るととを当然のととと考えているのかす知 れないが，その反面，何枚かを重ねて測定してあよいと とを意味しているのかむしれない.一応重ね枚数は測秗 者の任意であるとしてす，1 回の測定に 5 枚，10枚と多 数枚重ねることは考えられない. 大体 1 枚程度が普 通であろう. 実際には圧縮弾性試験と同じように 3 枚重 ねて測定し，その值を $1 / 3$ して厚さを求めているてとが 多い. 1 枚で測る場合, 編地に加わる圧力はプレッサー 
フートによる荷重のみであるが，何枚か重ねた場合，一 番下の試料には，わずかではあるが上に重ねた試料の自 重も加わるととになる。

試料を重ねる場合の試料の方向によってあ測定値にわ ずかであるが差がみられる３枚の試料を重ねる場合， 試料のウェールが交互に直角になるように重ねたとき と，3枚のウェールを平行にして重ねたときとではわず かに差がみられるが定量的に確かなととはまだいえな い.また，1枚で測定した場合と，3枚で測定した場合 の厚さにはわずかに差がみられるが，てれについてあま だ確定的なととはいえない。試料の重ね枚数と重ねる方 向については今後の検討を要するが，J I Sで定めてい る方法でだいたいよいあのと考えている。

\section{2 プレッサーフートの面積}

B S，A S TMとも 1 つの值を決めていない，BSで は 0.25 in $^{2} \sim 16$ in ${ }^{2}$ (または $1 \mathrm{~cm}^{2} \sim 100 \mathrm{~cm}^{2}$ ) と範囲で 示している. J I S (L 1018 改正案) では $5 \mathrm{~cm}^{2}$ を原 則とするととにし，その他の面積のあのを使用したとき は面積を示すととにしてある.

プレッサーフートの面積の大小によって測定値にど の程度の誤差がでるかについては，プレッサーフート の面積が $1 / 2$ in $2 \sim 2$ in ${ }^{2}$ の範囲で約 $3 \%$ 程度との報告が ある・プレッサーフートの面積が大きいと部分的に厚 い部分を測る可能性むあり，できれば小さい面積で測る ほうがよいといわれている.しかし，素材，組織などに よって一概にどちらがよいとはいい切れない。編地の場 合，あまり大きい圧力を加えて測ることができないし， 小さい圧力を加えるのは大きい圧力を加えるよりす実際 上むずかしいから，できるだけプレッサーフートの面 積を大きくして, 比較的大きい荷重を加えてあ単位面積 当たりの圧力を小ならしめる方法を取るほうが操作上便 利である.

\section{3 加 圧 時 間}

加圧時間に関して, B S 法では指針が動かなくなるま で，あるいは厚さが落ち付くまで，の表現をとってい る. A S TMでは $5 \mathrm{sec}$ 間で全荷重を加え， $5 \mathrm{sec}$ 間放 置することになっている，J I S 法では $10 \mathrm{sec}$ 間と決め ている.

従来の経験からも約 $10 \mathrm{sec}$ 程度の時間でよいと考えら れる.特殊な編地，太い系で編んだ編地などでは圧力が 小さい場合 $10 \mathrm{sec}$ 程度の加圧時間では不十分な場合むあ る.しかし, 一般的には加圧時間によって結果が大きく 変化するととはまず考えられない。

\section{4 プレッサー フートの降下速度}

降下速度について，B Sでは $2 / 1000$ in/sec の速度と 決めているが，他の試験法では明示されていない. B S のての速度は実際に守られているかどうか疑問も感ぜら れる. 常にての速度を一定にして試験するのはむずかし い. しかし，降下速度は厚さの測定には影響を与える因 子であるてとは確かであって，プレッサーフートを急 激に落下させた時とゆっくり降したときとでは明らかに 差がみられる。できるだけゆっくり一定の速度を保つよ うにすべきである.

\section{5 加える圧力}

厚さの測定に影響を及ぼす種々の因子のうち最も影響 の大きいのは加える圧力である．第 3 表の実測例につい て, 加える圧力と厚さの関係を図示すると第 7 図のよう になる，乙の図でわかるように，厚さは圧力の小さい領 域での変動の大きいととが 3 種の編地のいずれについて あむいうととができる. 圧力の大きい領域では $100 \mathrm{~g} / \mathrm{cm}^{2}$ の圧力を $200 \mathrm{~g} / \mathrm{cm}^{2}$ にしてあそれ活ど厚さが変わるとと はないであろう。しかし, 逆に $3 \mathrm{~g} / \mathrm{cm}^{2}$ 以下の場合, 図 上の線を下へ伸ばして圧力ゼロのときの厚さを推定する のは, 低圧力域での厚さの変動が大きいから, 単純に線 上に乗っでくるかどうかはわからない，したがって厚さ 測定時の圧力としては，繰り返し測定を行なっても常に ある一定の值をなるべく小さい誤差内で示し得るような 圧力があるととが望ましい.

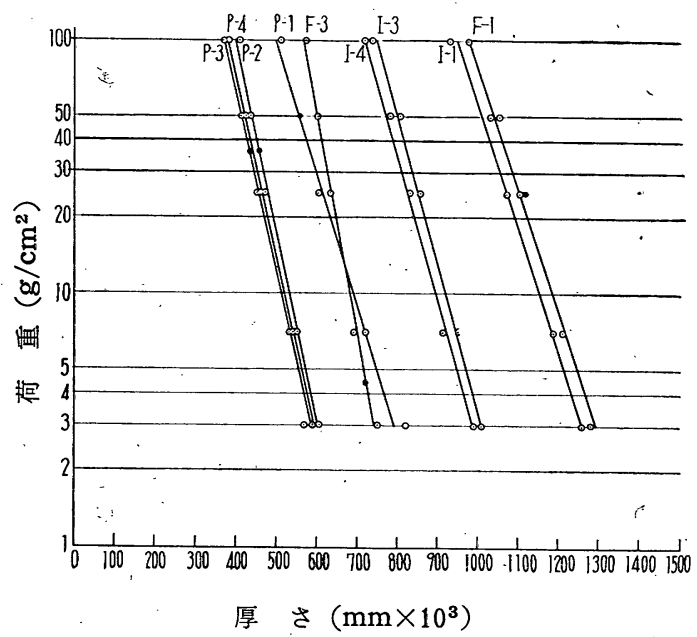

（第 7 図）厚さと荷重の関係（実測値）

Kaswell らによれば，衣服が着用中に 皮鹰に与える 圧力は 0.1 psi 程度であるといわれている．実際に衣服 を着用しているときの編地の厚さを考えるならば， 0.1 psi すなわち， $7 \mathrm{~g} / \mathrm{cm}^{2}$ 程度の圧力が一応の目安とな 
る.また数種の編地について, 圧縮一荷重曲線を描いた とき, 約 $7 \mathrm{~g} / \mathrm{cm}^{2}$ 程度が初荷重と考えられる圧力になっ ている.

試験法についてての圧力をどのように定めているかに ついて見ると，JIS では $7 \mathrm{~g} / \mathrm{cm}^{2}$ または $3 \mathrm{~g} / \mathrm{cm}^{2}$ の値

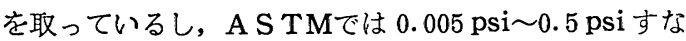
わち $0.35 \mathrm{~g} / \mathrm{cm}^{2} \sim 35.2 \mathrm{~g} / \mathrm{cm}^{2}$ である. $7 \mathrm{~g} / \mathrm{cm}^{2}$ は 0.1 psc に相当する值であり，JISの值はAＳTMの示して いる範囲内にある。

Smirfitt によれば, 平編地, ゴム編 $(1 \times 1)$ の厚 さと系直径および編目のループ長の間にはつぎのような 関係式が成り立つ?

$$
\begin{array}{cc}
\text { 平編地 } & t=0.090 l+\mathrm{d} \\
\text { ゴム編地 } & t=0.254 l+\mathrm{d} \\
\text { こてに } \quad t: \text { : 編地の厚さ }(\mathrm{mm}) \\
\quad l \text { : 編目の } 1 \text { ループ長 }(\mathrm{mm}) \\
d: \text { 糸直径 }(\mathrm{mm})
\end{array}
$$

第 3 表の $t_{0}$ の值は実測值の $l$ とdをての式にあては めて計算して求めた值である．との理論式と実測值の関 係は第 7 図に示されている．実測值と理論式を比べると その傾向がよく合っているのがわかる. しかし，乙の式 がよくあてはまるのは紡績系で $l$ がある範囲にある場合 であって，lの非常に小なるとき，非常に大きいときに はうまくあてはまらない．実際には $l$ の非常に大きい編 地は実用になりにくいから，実用される編地の籁囲では 式は成り立つとみてよいｌの非常に小さいのは伸縮性 加工系の場合であり，見かけの $l$ と伸ばしたときの $l$ と の間任差があり，縮伸性系は別に考えるほうがよいよう である．理論式で得られた厚さの値を示す圧力は編地に よって一定しないが, 平編地では約 $25 \mathrm{~g} / \mathrm{cm}^{2}$ 程度,ゴム 編地では約 $7 \mathrm{~g} / \mathrm{cm}^{2}$ 程度である.とれらを考えに入れる と厚さ測定時の圧力としては，JIS で採用している $7 \mathrm{~g}$ $/ \mathrm{cm}^{2}$ 程度で妥当であると考えている。

\section{5.むす び}

以上述ベたととをまとめると，

（1）編地のかさ高さを編地の単位重量当たりの容積 之定義する

（2）功高さを測定するには，編地の重さと厚さを 正確に測定する必要がある

（3）厚さを測定するには荷重ゼロの状態で測るとと
が望ましいが，覞実には不可能である・したが って，ある荷重を加えたときの厚さを編地の厚 さと定義する

（4）重さと厚さの測定とでは厚さの測定の方がむず かしい

（5）厚さの測定に際し，結果に影響を与える因子と しては, 試料の重敉枚数, プレッサーフート の面積, 加圧時間, プ.レッサーフートの降下 速度，加える荷重などがある

（6）上記の因子のうちでは加える荷重の影響が最も 大きい

（7）荷重と厚さの間の関係を見ると, 荷重の小さな 領域では厚さの変動が大きく, 荷重の大きい領 域では厚さの変動は比較的小さい

（8）編地の厚さを求めるにはなるべく荷重の小なる ことが望ましい，理論式から得た厚さの值を見 ると，小なる荷重で測定したときの值に近い值 を示す

（9）JISでは荷重を $7 \mathrm{~g} / \mathrm{cm}^{2}$ と $3 \mathrm{~g} / \mathrm{cm}^{2}$ の.2 種を 決めているが，乙の值は外国で定めている值の 範囲にもはいる，また衣服着用時の皮膚圧など から考えてもこの值は妥当な值と見られる

（10）今後の課題としては，いろいろな組織の編地と 素材に適した荷重の值を研究することと, 編物 に適した厚さ定測器を開発するととがあろう

\section{文献}

1) JIS L 1018 メリヤス生地試験方法（改正案）

2) ASTM Designation, D 1777-60T Tentative Method for Measuring Thickness of Textile Materials. ASTM Standards on Textile Materials 31-st Edition-1960 p.p. 788

3) B. S. $2544 ; 1954$ Determination of Thickness of Textile Fabrics. B. S. Handbook No. 111963 p. p. 174

4) S. L. Anderson; J. Text. Inst., 111961

5) E. R. Kaswell, L. Barish, C. A. Lermond; J. Text. Inst, 52 (No. 9. 1961) 508

6）メリヤス検査協会研究報告（未発表）

7) J. A. Smirfitt; J. Text. Inst., 56 T248 (1965)

8）川崎；メリヤス研究委員会資料第 10 回（昭 42 年 6 月)

福岡; メリヤス研究委員会資料 第 8 回（昭和 42 年 2 月) 